\title{
Entrepreneurship as a career option for woman: An overview of research
}

\author{
Ronel Erwee \\ Graduate School of Management, University of Pretoria, Pretoria, 0002 Republic of South-Africa
}

Accepted 7 March 1987

\begin{abstract}
Entrepreneurship is seen as a non-traditional career option for women and most of the available research on this career focus on the male entrepreneur. A life-cycle model of career development is used as basis to systematize the review of the few studies of female entrepreneurs. Research on factors influencing the devclopmental history of women entrepreneurs, namely their education and training, personality traits, childhood family environment, work history, adult developmental history and adult family history, are grouped together for discussion. Factors affecting the women entrepreneurs' current situation are discussed separately. Research on female entrepreneurs in two different cultures are contrasted and areas for research on women entrepreneurs in South Africa are discussed.
\end{abstract}

\begin{abstract}
Aangesien entrepreneurskap as 'n nie-tradisionele loopbaankeuse vir vroue beskou word, fokus meeste van die bestaande navorsing oor entrepreneurskap op die manlike entrepreneur. Hierdie oorsig van navorsing oor die vroue-entrepreneur benut ' $n$ lewensiklus-model ten einde die bestaande navorsing te sistematiseer. Gevolglik word navorsing oor faktore wat die ontwikkeling van entrepreneurskap by die vrou beïnvloed, gegroepeer en word inligting oor hul opvoedkundige geskiedenis, persoonlikheidstrekke, gesinsgeskiedenis, werkservaring en volwasse-ontwikkeling ingesluit. Faktore wat die vroue-entrepreneur se huidige funksionering beïnvloed, word afsonderlik bespreek. Navorsing oor vroue-entrepreneurs in twee verskillende kulture word gekontrasteer en voorstelle vir navorsing oor vroue-entrepreneurs in Suid-Afrika word aangebied.
\end{abstract}

A new trend that is emerging world-wide is 'entrepreneurial fever' (Bowen \& Hisrich, 1986; Devine \& Clutterbuck, 1985; Rupert, 1985). Shapero (1985:5) cited the reasons for the wide-spread interest in entrepreneurship as 'Entrepreneurship is a profound, pervasive human process offering independence and opportunities for self-expression for the individual and the focussed motivation and behavior appropriate to today's national and international marketplace. Most of all, entrepreneurship provides communities with the diversity and dynamism that not only ensures continuous development, but also an environment in which personal freedom and individual rights can flourish'. He defined the sources of the current interest in entrepreneurship as the revitalizing effect entrepreneurship can have in depressed economies, the unease individuals are feeling with being 'held hostage' by large institutions and a shift in values from needing security of employment to a concern with self-expression and independence from large institutions. The signs of interest in entrepreneurship is manifested on national levels by government programmes but also on an individual level by a significant growth in self-employment. Entrepreneurship is being seen as a new career option for both men and women.

Currently much attention is focused on stimulating small business development in South Africa by providing financial incentives, creating infrastructure and deregulating restrictive legislation. It is hoped that this stimulation on a macro level will aid job creation in the current recession. One should not lose sight of the fact that the success of a small business also depends on the initiative of an individual entrepreneur to create a viable venture. Discovering the factors which encourage the individual to embark on an entrepreneurial career therefore also becomes an important factor in stimulating entrepreneurship.
Most of the knowledge of entrepreneurs seems to be of male entrepreneurs and focus mainly on the characteristics of successful entrepreneurs (De Vries, 1977) or social dimensions of entrepreneurship (Shapero, 1980). Knowledge of entrepreneurship as a career option for women seems to be lacking.

Some of the known trends in this area are that more women are deciding not to pursue the traditional career routes but are choosing to start their own businesses. Entrepreneurship is still viewed as a non-traditional career route in Europe (Devine \& Clutterbuck, 1985) and South Africa (Van Zyl, 1985) but is rapidly gaining acceptance in the United States (USA). Noble (1986) mentioned that women-owned businesses is the fastest growing segment of the small business population in the USA, increasing $6,9 \%$ yearly from 1977 to 1982 , compared with the 3,7\% growth of male-owned companies. Bowen \& Hisrich (1986) stated that the level of female self-employment increased from 1475000 in 1972 to more than 2330000 in 1981 . It is estimated that in $198231,8 \%$ of the self-employed people in the USA were women. These last statistics refer to businesses outside the home but Munro (1986) stated that there is an increasing trend to operate a business from home $26 \%$ of USA households do some kind of work from home and of these $44 \%$ own their own businesses. In Britain employment statistics indicate that $6 \%$ of businesses are owned and controlled by women (Devine \& Clutterbuck, 1985).

No comparable statistics for the proportion of South African businesses owned by women, are available. Mkalipe (1984) did estimate that about $70 \%$ of small businesses owned by blacks, were run by women. An analysis of black business enterprises by Kroon (1984) found that there were 7555 businesses in black residential areas in South Africa. These enterprises cater 
for 4 million residents, indicating the scope for entrepreneurship in these areas.

The aim of this paper is to review studies on entrepreneurship as a career option for women. The model formulated by Bowen \& Hisrich (1986, see Figure 1) will be used to structure this review of the available South African and overseas studies.

\section{Entrepreneurship as a career option}

Shapero (1980) argued that as 'entrepreneurship' is defined in a multitude of different ways by various scholars, one should focus on the entrepreneurial event rather than the entrepreneur. He defined the entrepreneurial event as having the following characteristics: an initiative is taken by an individual or a group; resources are brought together in organizational form to accomplish some objective; this organization is managed; the entrepreneurs have relative autonomy to dispose of and distribute resources and a measure of risk-taking takes place.

Although the above-mentioned definition can be applied to male as well as female entrepreneurs, the literature about entrepreneurship is almost exclusively focused on male entrepreneurs (Bowen \& Hisrich, 1986). A few recent international studies on female entrepreneurs have been located: AMA Survey, 1978; Devine and Clutterbuck, 1985; Hisrich and Brush, 1984; Munro, 1968; Schreier, 1976; Surti and Sarupia, 1983. Slabbert (1982) described 60 ongoing research projects on black entrepreneurs in South Africa - only one study on female entrepreneurs in South Africa is mentioned, but this study was never completed.

Paralleling the research on entrepreneurship, research on career theory has also been expanding rapidly. Sonnenfeld \& Kotter (1982) have indicated that four major phases in the historical development of career theory can be identified, viz, a social structure approach; a personality trait approach; a focus on career stages and recently a life-cycle theory. Bowen \& Hisrich (1986) noted that research of entrepreneurship as a career option can be classified as using the older social structure or static personality-trait approaches. In reviews of the literature on career development (Borgen, Layton, Veenhuizen \& Johnson, 1985) no mention was made of entrepreneurship as a career for women. Perun \& Bielby (1981) stated that a major revision of existing theory of female occupational behaviour is necessary. They recommended that '... a solution to the current theoretical morass will be found only when women's occupational behavior is viewed from the human development paradigm which emphasizes process, comprehensiveness and a life course perspective' (p. 249).

Bowen \& Hisrich (1986) seemed to follow this recommendation because they used a life-cycle model to summarize research on female and male entrepreneurs (see Figure 1). The various categories in their model will also be used in this paper as a basis to present relevant research on female entrepreneurs.

THE UNDERLYYING OCCUPATIONAL STRUCTURE

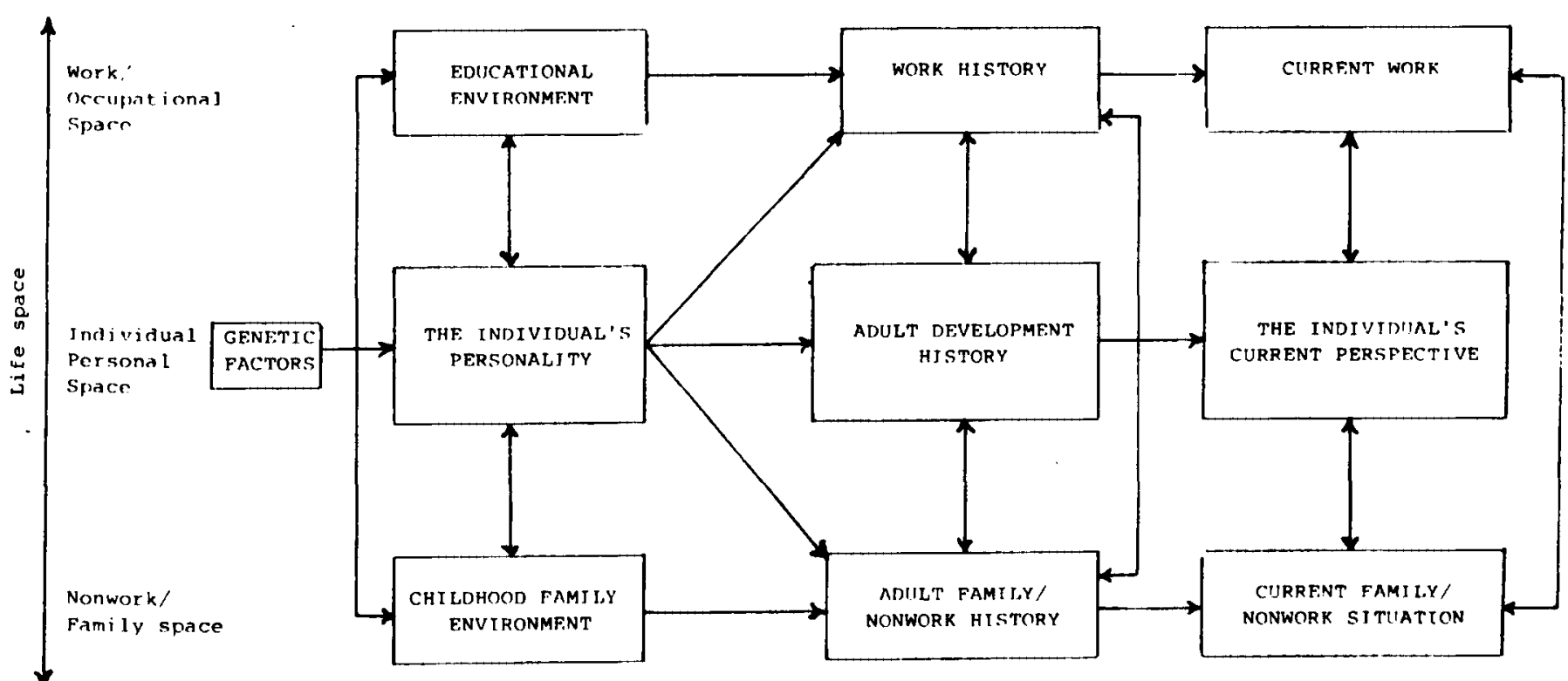

BROAD SOCIAL, ECONOMIC AND POLITICAL CONDITIONS

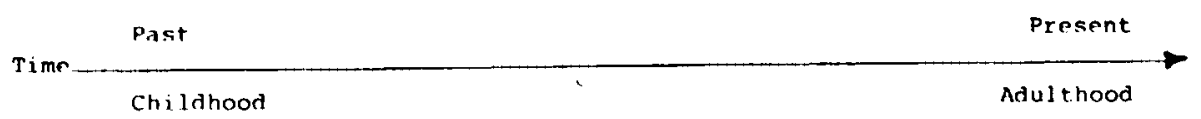

RINWFN \& HISRICH (1986)

Figure 1 Life-cycle model of career development 


\section{Entrepreneurial careers: A life-cycle model}

\section{Developmental history of the woman entrepreneur}

\section{Education and training}

From their summary of research on the educational level of American women entrepreneurs, Bowen \& Hisrich (1986) concluded that these entrepreneurs appear to be substantially better educated than the general populace. Hisrich \& Brush (1984) found that $70 \%$ of their respondents had liberal arts degrees with business administration as the most frequent major subject. Further related findings were that the parents of these women entrepreneurs were more highly educated than the general populace and that these women tended to marry more highly educated men. This trend was already evident in 1978 as can be seen from the AMA survey which indicated that almost half of their successful women entrepreneurs had bachelors or masters degrees (AMA Survey, 1978; see also Noble, 1986). Entrepreneurs who work from home also tend to be highly educated - twice as many as in the traditional work-force tend to have college and advanced degrees (Munro, 1986).

There is not much information about the educational qualifications of South African entrepreneurs (male or female). Both Motsunyane (1974) and Kutumela (1980) acknowledged that the black entrepreneur tends to lack any business background or training and is 'a graduate of the school of hard-knocks' (Motsunyane, 1974, p.12).

Black (1983) cited evidence that the lack of aptitude, ability to manage and experience have been major factors in the failure of small businesses world-wide - a concerted effort to increase education and training can improve the viability of the small business sector. Although much progress has been made in South Africa in directing resources to the small business sector Black (1983) observed that the scale on which education and training is being done is inadequate. A variety of different institutions are providing basic training courses, for example the National African Federated Chamber of Commerce, Universities and the Small Business Development Corporation. Many of these courses are directed at the retail sector and comparatively few courses are focused on other sectors. Black (1983) recommended that a needs-based approach to the development of training courses must be taken and that small business men and women must assist trainers in curriculum development.

Weinrauch (1984) stressed that entrepreneurs have certain basic fears about returning to some form of instruction such as adjusting to educational rules which contrast with the freedom and independence of owning a small business; translating abilities and interests into specific entrepreneurial skills and making significant investments in time and money. Birley (1985:9) stated that the New Enterprise Program in Britain is aimed at those potential entrepreneurs who see '... education as a way of delaying business formation' until they are reasonably certain that their business ideas are viable. In this programme trainees are carefully selected and training inputs are timed according to the stage of development of the business idea. It is not clear whether these concerns are taken into account by trainers of small business people in South Africa. Nelson (1979) did advocate that criteria such as experience, knowledge and attitude be applied in the selection of candidates for intensive training.

Mkalipe (1984) maintained that the success of many black women entrepreneurs can be ascribed to the fact that they are eager to avail themselves of any training opportunity. Some trainers state that black female entrepreneurs not only obtained better results than males in training courses, but also eventually achieve better results in business (Hoofstad, 1981).

Pottas (1981) has indicated that the concept 'entrepreneurship development' must be seen in a much broader context. Firstly, a distinction must be made between short and long-term solutions to the problem of developing/training the country's entrepreneurs. Secondly, both the short and long-term solutions can be implemented on two levels, that is a developmental level and a training level.

\section{Personality traits of entrepreneurs}

Although various investigators have researched the personality traits of entrepreneurs, there does not seem to be much consensus about which cluster of traits is the most important. Traits which have been researched separately are need for achievement, locus of control, risktaking and gender identity (Bowen \& Hisrich, 1986). De Vries (1977: 41) summarized his view on the entrepreneurial personality as follows: '...high achievement motivation is an important aspect ... but autonomy, independence, and moderate risk-taking are contributing factors'. He also described the entrepreneur as '....an anxious individual, a non-conformist poorly organized and not a stranger to self-destructive behavior ... inner directed ... selfreliant, ... and tend to deemphasize interpersonal relations' (De Vries, 1977: 41). These viewpoints are not supported by the data in most of the case studies on women entrepreneurs (see Venture, 1986).

In a review of studies on female entrepreneurs' achievement motivation, Bowen \& Hisrich (1986) reported that female entrepreneurs scored significantly higher than females in general on the achievement scale of the Edwards' Personal Preference Schedule. A further finding was that female entrepreneurs scored higher than secretaries, but not higher than female managers, on the Mehrabian Achievement Questionnaire.

In South Africa Pottas, Erwee, Boshoff \& Lessing (1980) developed the Achievement Motivation Questionnaire to study the level of achievement motivation among various groups. The five dimensions of the construct that are measured are persistence, awareness of time, action orientation, aspiration level and personal causation. Pottas (1981) found no significant sex differences in achievement motivation between male and female university students. He did find that black male and female students obtained higher scores $(p<0,001)$ than their white counterparts on all five dimensions. Based on these findings, Pottas (1981) contended that 
black university students are a more promising source of potential entrepreneurs than the white student groups. However, one must realize that this high need to achieve may be channelled into a variety of different directions - one of which may be new venture formation.

Shapero (1985: 3) was convinced that '.. the prime thing entrepreneurship offers is control over one's own life and independence is the primary driving motivation of the entrepreneur'. Bowen \& Hisrich (1986) summarized the research on the locus of control of entrepreneurs by pointing out that internal beliefs differentiate entrepreneurs from the larger population but not from other types of managers. With regard to female entrepreneurs, they concluded that the female entrepreneur may be more internal than her male counterpart.

Some South African researchers view locus of control as a unidimensional construct (see Moodley-Rajab \& Ramkissoon, 1979) whereas others view it as multidimensional (Barling, 1980; Erwee \& Pottas, 1982; Gilbert, 1980). Riordan (1981) stated that the results of past research regarding sex differences in locus of control have been contradictory. She found that significant sex differences were obtained when the total population was tested with males being more internal than females. However, within the four ethnic groups, that is whites, coloureds, Indians and blacks, the differences between males and females did not reach significance. No specific research on locus of control differences between male and female entrepreneurs has been undertaken in South Africa.

Certain researchers (Naumes, 1978; Timmons, 1979) declare that high achievement motivation in conjunction with internality are essential prerequisites for entrepreneurship. Borland (in Naumes, 1978) found significant differences in locus of control between USA business school students who expected to start a business and those who did not have such plans. Among the students who had a low need for achievement, those with a higher internal locus of control had greater expectations of starting a business than those with external scores. Among the group with a high need for achievement, locus of control had no significant impact on their expectations to form a company. Durand (1975) subjected black entrepreneurs to various training programmes and studied the effect of the training on their achievement motivation and locus of control. The two constructs tended to vary together - the achievement motivation training inputs were associated with a decrease in externality and an increase in achievement motivation.

South African researchers (see Erwee \& Pottas, 1982) found that locus of control and achievement motivation are significantly intercorrelated but that each of the two constructs manifests itself differently in the various cultural groups. It implies that in training courses aimed at enhancing entrepreneurial skills a) different emphasis on training inputs may need to be provided for each cultural or sex group, and b) such programmes should not only focus on strengthening achievement motivation but also on altering the individual's beliefs about locus of control.

With regard to research on the risk-taking propensity of entrepreneurs, Bowen \& Hisrich (1986) stated that there are few clear guidelines about the risk-taking behaviour of either sex. One study did indicate that both female entrepreneurs and female managers described themselves as moderate risk-takers. This tendency also emerged in a recent survey of readers of Venture magazine as $44 \%$ of the sample stated that they 'like to take some chances' while less than one third enjoy the 'thrill of going for it all' or 'only calculated risks' (Pollock \& Pollock, 1986). No comparable data are available on the risk-taking propensity of South African entrepreneurs.

The Bem Sex Role Inventory has been used frequently to study the gender identity of entrepreneurs. Bowen \& Hisrich (1986) cited studies which indicate that female entrepreneurs score high on traits usually associated with 'masculinity' such as autonomy, aggression, independence and leadership. Other studies indicate that female entrepreneurs place relatively low emphasis on aspects such as valuing family over occupation, wanting support for others and conformity. Ruhe (1986) compared women in large businesses to women entrepreneurs and found that the latter place great emphasis on '... cooperating effectively in groups, assessing readiness for change, controlling emotions and personal insight of strengths and weaknesses'. Some of these tendencies seem to be confirmed by case studies of women entrepreneurs (see Venture, 1986). Much of the data in the case studies are based on subjective interpretation by a writer of statements by the woman entrepreneur, making interpretation difficult.

Although the BSRI has been used in South African studies, none of these focused specifically on entrepreneurs.

\section{Childhood family environment}

De Vries (1977: 45) described the childhood of entrepreneurs as a 'very disturbing experience' by noting that 'desertion, death, neglect and poverty' are aspects which entrepreneurs frequently mention about their childhood. It is stated that the father is frequently blamed for having neglected the family and that the remoteness of the father image in the family is often complemented by the mother' and 'mothers who come across as strong, decisive, controlling women who give the family some sense of direction' (De Vries, 1977: 46).

Most other researchers do not share De Vries's negative views about entrepreneurial family dynamics. Hisrich \& Brush (1984) found that the majority of the women entrepreneurs in their samples had entrepreneurial fathers and $11 \%$ had entrepreneurial mothers (see also Schreier, 1976). The same tendency was reported by Devine \& Clutterbuck (1985) for British women entrepreneurs. These studies also indicated that the women entrepreneurs grew up in middle- to upperclass environments which provided the women with good role models. Schreier (1976: 40) hypothesized that '... entrepreneurs beget entrepreneurs'.

In South Africa, Krige (1975) did contrast the family interactional patterns of high-achieving and low- 
achieving girls, but did not speculate about the possibility that the high-achieving girls may be potential entrepreneurs.

\section{Work history}

Shapero (1980) formulated a model to indicate how previous work experience may interact with other factors to stimulate the decision to start a new venture. He focused on 'negative displacements'-such as dissatisfaction with a previous job, being a 'displaced person' (migrant, refugee) or certain more positive aspects such as being encouraged by a mentor to start a business. De Vries (1977: 51) hypothesized that '... the preparatory period of entrepreneurship ... is accompanied by authority conflicts, failures in organizational socialization, difficulties in adapting to organizational structure and predictable job-hopping behavior'.

Some evidence that the above-mentioned statements do apply to female entrepreneurs, is available. Cromie (1986) as well as Hisrich \& Brush (1984) reported that significant proportions of their samples noted that frustration in their previous job was a reason to start a new business. Devine \& Clutterbuck (1985) mentioned studies which indicated that a woman's decision to become an entrepreneur is often influenced by limited career prospects, lack of suitable qualifications and the need to fit work hours around the demands of a home and family rather than a desire to start a small business. Ochshorn (1986: 46) in analysing the reasons why a number of women entrepreneurs started a business stated they prefer the freedom of owning a business to the constraints of corporate life, in spite of the loneliness that is the price ... they see entrepreneurship as a way to be in control of their lives in a way that is simply not possible when they are part of someone else's team'.

Some South African examples of job-related displacements are young teachers who marry and forfeit their posts, a married woman who is forced to resign when she falls pregnant, and women managers who find their career paths blocked (Erwee, 1983).

Bowen \& Hisrich (1986) postulated that certain forms of negative displacement that are unique to women entrepreneurs are displacement in the home due to the empty-nest syndrome as well as widowhood and divorce. Many American women's magazines have regular features on women entrepreneurs and a significant proportion of these women are divorced or widowed (Bulger, 1982). Many potential female entrepreneurs in South Africa may also fall into this category due to the high incidence of divorce and coronary-related deaths among South African men.

Both De Vries (1977) and Shapero (1980) stated that migration and discrimination against minority groups are forms of displacement. In South Africa Human (1984: 218 ) indicated that certain 'minority' groups who are excluded from participation in the economy of the dominant group, tend to develop methods to overcome certain barriers and to exploit opportunities - such behaviour being a fertile ground for entrepreneurship. Another South African example is the participation of black women in the informal sector (Erwee, 1983). Many of the women vendors selling wares at bus stops have suffered the effects of rural to urban migration.

Shapero (1980) mentioned that when he asked a black South African businessman why he had started a business, the black told Shapero that he had worked for a Jewish businessman who had convinced him that he could do it. A South African women's organization, in conjunction with a leading magazine, also used the concept of stimulating interest in entrepreneurship by using positive role models.

\section{Adult developmental history}

Bowen \& Hisrich (1986) found that there have not been any studies of adult developmental history for female or male entrepreneurs. They noted that although adult developmental models play a central part in contemporary career development theories, that there are no life stage theories for women.

Both Gerdes (1981) and Van Rooyen (1984) have contributed to theories of the development of adult women in the South African context but have not specifically applied their views to female entrepreneurs.

\section{Adult family/non-work history}

According to research in the USA between 50 and $60 \%$ of any sample of female entrepreneurs are married (AMA Survey, 1978; Bowen \& Hisrich, 1986; Hisrich \& Brush, 1984; Schreier, 1976). In Surti \& Sarupia's (1983) Indian sample, $70 \%$ of the respondents were married. Few studies report on the number of children per household - Devine \& Clutterbuck did report that $75 \%$ of a group of British women entrepreneurs had children. Cromie (1986) noted that all of his sample of women entrepreneurs had children and had started their enterprises in an attempt to simultaneously take the roles of mother and careerist.

Bowen \& Hisrich (1986) observed that many female entrepreneurs stated that their husbands' support contributed to the success of their venture. A contrasting view is provided by Schreier (1976) who argued that the divorce rate among female entrepreneurs tend to be higher than the national average. Helm (1986: 38), in a recent analysis of entrepreneurial couples, emphasized that '... as women become more involved as partners in entrepreneurship, the risk to both members of the team doubles: if something goes wrong, they face the disolution of a business, as well as the breakup of a marriage'. Layman, Salganicoff \& Hollander (1985) also contended that the role of a wife as partner in a family business is multidimensional and difficult to manage. Surti \& Sarupia (1983) found that the married women entrepreneurs in their sample experienced significantly more role stress than their unmarried counterparts.

In South Africa an Afrikaans women's magazine recently sponsored a competition for the 'Small BusinessWomen of the Year'. Three hundred and fifty woman requested enrolment forms, 190 returned the forms and the data of 160 entrants were analysed (Erwee, 1987). 
Fifty-eight per cent of the entrants were Afrikaansspeaking and $42 \%$ were Englishspeaking (including some black women entrepreneurs).

The majority of these women entrepreneurs (73\%) were married, whereas only $12 \%$ were divorced; $8 \%$ were unmarried and 7\% were widows. Approximately half of these entrepreneurs indicated that they do not have dependent children anymore. This finding can be linked to the age of the women entrepreneurs - a significant group is over $\mathbf{4 5}$ years of age. Forty-eight per cent indicated that they have less than three dependent children. The majority of the South African women entrepreneurs were in the age categories $32-44$ years $(36 \%)$ and $45-56$ years $(32 \%)$. Twenty per cent of the group were younger than 30 years and $12 \%$ were older than 57 years. It seems as if the South African women entrepreneur tended to start her enterprise at a much younger age than her American counterpart.

\section{Current functioning of the woman entrepreneur}

\section{Current work situation}

The ventures created by female entrepreneurs seem to have certain characteristics in terms of the type, size, level of income and the way in which they are managed.

Bowen \& Hisrich (1986) observed that the type of businesses of female entrepreneurs tended to be concentrated in traditionally female industries such as retail, personal services and educational services. Hisrich \& Brush (1984) found certain types of businesses in their sample (see Table 1). An analysis of case studies (Venture, 1986) also reveals a diversity of different types of ventures and a greater movement into nontraditional fields. In discussing home businesses, Munro (1986) mentioned the following types: product manufacturing/ sales $(16 \%)$, crafts/handiwork $(11 \%)$, service industries $(24 \%)$, bookkeeping (10\%). The remaining $39 \%$ consisted of ventures such as information processing/ technology, education and consulting services and art and design.

The reasons why female entrepreneurs choose these

Table 1 Type of business: American women entrepreneurs $(n=468)$

\begin{tabular}{lc}
\hline Type of business & Percentage \\
\hline Sales & $20 \%$ \\
Consulting & $14 \%$ \\
Design/Art & $10 \%$ \\
Public Relations/Advertising & $8 \%$ \\
Personnel/Business Services & $8 \%$ \\
Computer related business & $8 \%$ \\
Manufacturing & $7 \%$ \\
Secretarial & $7 \%$ \\
Educational services & $6 \%$ \\
Law/Medical services & $5 \%$ \\
Distribution/Construction & $5 \%$ \\
Finance & $3 \%$ \\
\hline
\end{tabular}

Hisrich \& Brush (1984) types of businesses, vary. Bowen \& Hisrich (1986) argued that the female entrepreneur's possible lack of educational and work experience in technical and business fields, usually dominated by males, may limit her opportunities in such areas. Hisrich \& Brush (1984) concluded that few women entrepreneurs enter new markets with distincly new inventions because they prefer to compete in existing markets. Munro (1986) noted that the crafts field is expanding because the market increasingly values work done by hand in a technological society.

A few studies reported that the income level of female-owned businesses tended to be lower than maleowned businesses in the same industry. Hisrich \& Brush (1984) found that gross business revenues in their sample were the following:

Less than $\$ 30000-20 \%$

$\$ 30000-\$ 99999-27 \%$

$\$ 100000-\$ 499999-32 \%$

More than $\$ 500000-19 \%$

They did concede that these relatively low revenues are due to the short periods of time in operation (four years) and the predominance of service sector businesses. In contrast to these findings, the majority of case studies referred to in Venture (1986) reported gross business revenue between $\$ 250000-\$ 10000$ million. Even Munro (1986) stated that home business-owners are 'affluent' twice as many as in the traditional work-force earn more than $\$ 40000$ per year. These home businesses had also been operating for about two - four years and most owners preferred to keep them small.

The 'smallness' of the enterprise is also reflected by the number of employees per business. Hisrich \& Brush (1984) reported that $30 \%$ of female entrepreneurs employed no workers (other than the entrepreneur herself), whereas $42 \%$ had only one to four full-time employees. Munro (1986) noted that only one third of home businesses employ other household members whereas $10 \%$ employ outside help. This has an impact on the number of hours that the female entrepreneur has to work. Bowen \& Hisrich (1986) indicate that women entrepreneurs work an average of 50 hours per week.

All women entrepreneurs do not place equal emphasis on expanding their business. Bowen \& Hisrich (1986: 403) reported studies which indicated that 'a feeling of personal achievement', 'being my own boss' and 'a feeling of responsibility' were all rated as more important reasons for job satisfaction by female entrepreneurs than 'growth of the business'. These findings are supported by Gumpert (1984) and Ochshorn (1986). Gumpert (1984) noted that the challenge for the female entrepreneur is to run her business in a way which will allow her to achieve financial and quality of life goals. By placing high priorities on personal issues such as 'working at home' or 'tending my family', female entrepreneurs may fail to adequately finance their business or market their product.

There seems to be a difference in the way in which male and female entrepreneurs manage their businesses. De Vries (1977: 53) declared that the enterprise of a male entrepreneur is 'run in a very autocratic directive 
way whereby all the decision-making processes center around the entrepreneur ... an individual who refuses to delegate, is impulsive, lacks any interest in conscious, analytical forms of planning and engages regularly in bold proactive moves'. In contrast to this Devine \& Clutterbuck $(1985 ; 6)$ quoted research as indicating that female entrepreneurs create businesses that are "cooperative, loosely hierarchial and fluid in method of functioning ... the women entrepreneur is more concerned with work relationships, is less conscious of her authority and uses her authority more flexibly than a male entrepreneur'. Some women entrepreneurs excel at starting a company and nursing it through the difficult stages, but find it hard to retreat and allow the company to become more structured (Bowen \& Hisrich, 1986; Devine \& Clutterbuck, 1985).

In South Africa the Small Business Development Corporation defines a small business as one which is privately owned, has a turnover of less than $\mathrm{RI}$ million per year, assets not exceeding R500 000 and employing less than 100 employees. During a recent seminar (Erwee, 1986) for potential 'home entrepreneurs', it was found that most of the participants were interested in starting typically female enterprises such as craft groups, daycare centres, catering services and bookkeeping services. Certain non-traditional ventures were also mentioned such as exporting machinery, international commodity brokering, waste recycling, financial consulting and businesses in the transport and construction industries.

The type of businesses of the sample of South African women entrepreneurs (Erwee, 1987) also tended to be concentrated in traditionally female enterprises (see Table 2). Many ( $46 \%$ ) of these enterprises had been operational for only one - three years. Twenty-two per cent of the businesses had 'survived' for four - six years whereas a further $25 \%$ had been in existence for $7-15$ years. A few women entrepreneurs (7\%) had been running their businesses for more than 16 years (Erwee, 1987).

Table 2 Type of business: South African women entrepreneurs $(n=160)$

\begin{tabular}{lc}
\hline Type of business & Percentage \\
\hline General dealer & $29 \%$ \\
Personal services & $10 \%$ \\
Manufacturing (mainly clothes, small scale) & $10 \%$ \\
Crafts & $9 \%$ \\
Retail & $8 \%$ \\
Public relations/marketing & $8 \%$ \\
Personnel/business services & $6 \%$ \\
Transport & $5 \%$ \\
Design/Art & $4 \%$ \\
Manufacturing (e.g. chemical products) & $3 \%$ \\
Estate agency & $3 \%$ \\
Legal/financial services & $2 \%$ \\
Farming/other & $2 \%$ \\
Travel bureau & $1 \%$ \\
\hline
\end{tabular}

Erwee, 1987
The majority $(73 \%)$ of the women entrepreneurs were sole proprietors of their ventures with the rest establishing partnerships (Erwee, 1987). More than half of the sample noted that they only used their own capital to establish their business rather than use borrowed capital. Although most entrepreneurs (44\%) could not provide information on their initial capital outlay, $40 \%$ mentioned that they used less than R12000 whereas the rest used between R12000 - R30 000 .

Forty per cent of the South African women entrepreneurs (Erwee, 1987) did not provide adequate information on the annual income level of their enterprise, whereas the rest did provide the necessary information (see Table 3). The two significant categories of annual turnover seem to be less than R10 $000(24 \%)$ and more than R500 $000(18 \%)$. These relatively low annual turnover figures can again be linked to predominance of service-orientated businesses and their short periods of operation.

Table 3 Annual turnover or business: South African women entrepreneurs

\begin{tabular}{lc}
\hline Annual turnover & Percentage \\
\hline R $1000-$ R 49000 & $9 \%$ \\
R $50000-$ R 99000 & $15 \%$ \\
R100 000-R149 999 & $6 \%$ \\
R150 000-R199 999 & $3 \%$ \\
R200 000-R249 999 & $3 \%$ \\
R250 000 - R499 999 & $7 \%$ \\
More than R500 000 & $18 \%$ \\
\hline
\end{tabular}

Erwee, 1987

South African women entrepreneurs seem to actively contribute to job creation. Fifty-four per cent (Erwee, 1987) stated that they only created an employment opportunity for themselves or one other person when they initially started their venture. Thirty-four per cent initially employed two - five people whereas the rest employed more than six people (full-time posts). Currently, only $46 \%$ still have a small staff (one - six people). Thirty-two per cent of the women entrepreneurs already provide work to $7-20$ staff members, and $22 \%$ employ more than 20 staff members.

\section{The entrepreneur's current perspective and problems}

Munro (1986) noted that two out of three new businesses, home-based or not, failed within their first year. Hisrich \& Brush (1984) indicated that the typical problems women entrepreneurs faced are difficulty in obtaining credit, lack of collateral, lack of business and financial training and difficulty in obtaining expert advice.

Bowen \& Hisrich (1986) maintained that women entrepreneurs are ineffective in obtaining credit because of a lack of financial expertise and a lack of self-confidence. However, female entrepreneurs tended to accuse the financial institutions of discrimination (AMA Survey, 
1978). Black (1986) quoted a recent survey which found that $75 \%$ of the National Association of Women Business Owners (NAWBO) had applied for commercial credit during the past five years. Thirty-eight per cent of these applicants had been denied loans - of these $62 \%$ believed that they had been discriminated against on the basis of sex. Of those entrepreneurs who had obtained loans, $29 \%$ percent believed that the terms of the loan had been discriminatory. Fortunately American women entrepreneurs have access to a variety of financial sources such as the Small Business Administration, Women's National Bank, venture capital firms, financial syndicates, private investors and loans from family and friends.

Shapero (1980) stated that the entrepreneur's view of the desirability to start a business may be influenced by the perceived support of the family. Gumpert (1984) also noted that for married women this is a crucial issue, as a husband with a demanding career may not wish to 'compete' with his wife's enterprise. However, a new trend seems to be emerging - a decade ago, husbands generally started ventures on their own with limited help from their wives (Helm, 1986). Currently husband and wife teams are cofounders and co-owners of businesses. Surti \& Sarupia (1983) found that Indian women entrepreneurs who are part of a joint family structure experience less role conflict because of active support by family members.

Another source of support which is becoming more crucial, is networks of women entrepreneurs. More than a thousand such networks have been founded in the USA during the past decade to 'address the professional and emotional needs of the growing number of women entering the workforce' (Black, 1986). These networks offer training seminars, individual consulting, regular meetings, conferences, trade fairs, newsletters and in some cases revolving loan funds for members.

Devine \& Clutterbuck (1985) reported that training courses to enhance the skills of British women entrepreneurs were relatively scarce. In the USA the above-mentioned networks provide training and most business schools in large universities offer courses in small business development in degree programmes or present special seminars.

Schreier (1976: 43) noted that women's self-image may be a debilitating or a positive factor in new venture formation. Some of the women in his sample felt that they initially had to 'sacrifice some of their femininity' but that they eventually 'got it back'. However, most women entrepreneurs perceived themselves as women who have performed on their own and have proven that they are successful - this positive self-image helped them to expand their business (Noble, 1986).

The Small Business Development Corporation in South Africa makes finance available to entrepreneurs providing that they present a viable business plan. Some banks have established a section to offer financial advice to small business owners. It is difficult to ascertain whether these institutions discriminate against women entrepreneurs. One particular financial institution did sponsor a nation-wide series of seminars to stimulate interest in home entrepreneurship among women and has been sponsoring the Women's Bureau of South Africa. The latter organization is one of the leading women's networks and has a committee on 'Women in small business'. The Bureau initiated an employment creation project which stimulated the above-mentioned series of seminars (Erwee, 1986). A number of women entrepreneurs have formed networks which provide training courses and newsletters to members.

Each entrant to the South African 'Small BusinessWoman of the Year' competition (Erwee, 1987) had to indicate why she should win the award. An analysis of these statements revealed a number of themes:

I had to overcome many obstacles $-44 \%$

I have many entrepreneurial characteristics - $41 \%$

My business is expanding rapidly $-32 \%$

I have created jobs $-30 \%$

My family/friends support me/the venture $-26 \%$

I created something new/unique $-22 \%$

I entered a 'male-dominated' field $-16 \%$

I teach my staff new skills $-15 \%$

I am the sole proprietor - $9 \%$

The women entrepreneurs included more than one theme in their stories. The majority emphasized the many obstacles they had to surmount as women entrepreneurs. These obstacles included a lack of business knowledge and -experience, inadequate financing and difficulty in obtaining credit, poor marketing of their services, restricting municipal bylaws and resistance from the market. The entrepreneurs believed that certain entrepreneurial characteristics such as persistence, a willingness to work hard, confidence in their abilities, autonomy and a need to achieve, contributed to their success. The entrepreneurs were also proud of the fact that they could create jobs and train others. Many believed that their enterprises had a relatively high growth rate and others noted that they were the only women operating in a male-dominated field such as transport. Many women entrepreneurs mentioned the encouragement which they received from their family or friends to become an entrepreneur.

\section{Broad social, economic and political conditions}

Bowen \& Hisrich (1986) did not address this particular aspect in the model as these factors focused attention on macro issues in the environment, which were outside the scope of their review.

In a South African context these factors have a major impact on an entrepreneur's decision to start a business in a society which not only is experiencing a recession but also the threat of economic sanctions and social upheaval caused by high unemployment. According to De Villiers (1986) the Government has accepted that the small business sector plays an important role in the country's economic development and therefore will implement recommendations on the removal of restrictions on small business development. They have also accepted that discriminatory legislation applicable to business men of the Asian, black and coloured population groups 
be repealed so that equivalence for all businessmen can be achieved. One hopes that this principle of nondiscrimination will also be applied to female entrepreneurs of all races.

Pottas (1981) has indicated that the concept 'entrepreneurship development' must be seen in a societal context. Firstly, a distinction must be made between short and long-term solutions to the problem of developing/training the country's entrepreneurs. Secondly, both the short and long-term solutions can be implemented on two levels, that is a developmental level and a training level. In the short term fairly drastic measures must be taken to provide the country with high-quality entrepreneurs. On the developmental level those personal characteristics which distinguish a successful entrepreneur must be identified and developed. This type of developmental effort must be supported by training in aspects of management and venture formation. Focusing on only short-term solutions will be insufficient - a total long-term strategy must be evolved. This type of strategy must be supported by actions such as instituting courses at appropriate levels in school which will prepare potential entrepreneurs for the intricacies of competing in the free enterprise system.

\section{Conclusions and recommendations for future re- search}

Bowen \& Hisrich (1986: 404) formulated a few tentative generalizations from their research namely that American women entrepreneurs are a) relatively welleducated in general, but perhaps not in management skills, b) high in internal locus of control, c) more 'masculine or instrumental' than other women in their values, d) likely to have had entrepreneurial fathers, e) relatively likely to have been first-born or only children, f) unlikely to establish a business in traditionally maledominated industries, g) likely to be married, h) seldom owners of large businesses, and i) experiencing a need for additional managerial training.

One can draw a few conclusions from the limited sample of South African women entrepreneurs namely that this sample a) included more Afrikaansspeaking entrepreneurs as the readership of the magazine is predominantly Afrikaans, b) consisted of mostly married women in the age groups 32 to 56 years of age who had few dependent children, c) were mainly general dealers or active in service and small manufacturing enterprises, d) had established their businesses fairly recently (one six years ago),e) tended to be sole proprietors who started the business with their own capital and with a relatively small capital outlay, $f$ ) contributed to job creation as their personnel had increased since the establishment of their business, and $g$ ) believed that they had overcome many obstacles in establishing and managing their venture.

It is clear from this review that entrepreneurship as a career option for females has not been adequately researched in America, Europe or South Africa. The studies which have been quoted suffer from certain inadequacies: the samples are small and not representative; research designs are cross-sectional and not longitudinal; measuring instruments are not always reliable and valid; basic descriptive statistics can be used on the data sets.

Bowen \& Hisrich (1986: 404) stated that the 'patch. work of findings' contributes little to the development of a theory of female entrepreneurship. Few generalizations can be drawn from this data base and many areas in the life-cycle model seem to have been overlooked by researchers. Cromie (1986) also cautioned researchers not to use sexually biased models to study male and female entrepreneurs. His studies indicated that while there are many similarities between male and female entrepreneurs, there are significant differences too.

In the South African context, where small business development is now crucial, almost no data are available. Information is needed on all aspects of male and female entrepreneurship (of all races) to build a model of the viability of entrepreneurship as a career option.

A number of recommendations for future South African research, using the life-cycle model, can be made. The interrelationship between certain personality variables (achievement motivation, locus of control and risk-taking) of successful entrepreneurs needs to be studied by using instruments validated for South African samples. Aspects of the childhood family environment such as the impact of an entrepreneurial parent as a role model, may be included. The contribution of these factors to the success of the entrepreneur must be assessed.

If the career route of the female entrepreneur is studied, her previous work history need to be investigated. The hypotheses that female entrepreneurship is stimulated by job dissatisfaction or negative displacement (in the work situation or at home) must be tested. The life and career stage at which entrepreneurship becomes a viable option can be explored. The effect of her previous work experience and training on her choice of a particular type of venture can be investigated.

The support of the married female entrepreneur's family for her choice and in the running of the business may prove to be important. It can be ascertained whether a family business, being part of an entrepreneurial couple, or home entrepreneurship create specific stressors for the female entrepreneur.

Data are also needed on the types of businesses that are created, their size in terms of assets, turnover and number of personnel. The work environment that the entrepreneur creates for herself and her staff by means of her managerial style or other factors, can be analysed. This information may prove to be valuable in career counseling of prospective entrepreneurs.

Societal, economical and political factors will remain as constraints which will effect the viability of entrepreneurship as a career for South African women of all races. The effect of restrictive legislation and prohibitive regulations at local government level on new venture formation need to be documented and eliminated. As entrepreneurship is a non-traditional career option for women, changes in societal attitudes regarding this option need to be monitored.

Research on the above-mentioned issues may provide 
a data base on which a model of female entrepreneurship in South Africa can be constructed.

Despite the many unanswered research questions, the future for women entrepreneurs seems to be very bright. Over the past decade there has been a significant growth in women-owned businesses world-wide. This implies that women entrepreneurs will no longer be a 'minority' in absolute numbers - which may lead financial institutions, suppliers and clients to become less sceptical of the viability of a woman-owned enterprise. Since many enterprises have only recently been established, one can hope that they may experience significant growth despite current recessions. In managing her enterprise the woman entrepreneur may still face difficult choices such as balancing the expansion of her business with the needs of her family. As more women become economically independent through entrepreneurship, new role models are created which may lead young women to consider entrepreneurship as a career option.

\section{References}

AMA survey. 1978. Women at work: AMA Survey shows how and why females succeed as business owners. Manage Rev., 56, November 6.

Barling, J. 1980. Multidimensional locus of control beliefs among English speaking South African mothers. J. Social Psychol., III, 130-140.

Black, P. 1986. A little help from her friends. Venture, July, 52-58.

Black, S. 1983. The development and training of small business entrepreneurs. Unpublished symposium paper, Johannesburg, May.

Birley, S. 1985. Encouraging entrepreneurship: Britain's New Enterprise program. J. Small Bus. Manage., October, 6-12.

Borgen, F.H., Layton, W.L., Veenhuizen, D.L. \& Johnson, D.J. 1985. Vocational behaviour and career development, 1984: a review. J. Vocat. Behav., 27, 218-269.

Bowen, D.D. \& Hisrich, R.D. 1986. The female entrepreneur: a career development perspective. Acad. Manage. Rev., 11, 2, 393-407.

Bulger, M. 1982. The right to be your own boss. New Woman, May, 26-27.

Cromie, S. 1986. Some similarities and differences between men and women who choose business proprietorship as a career. Paper delivered at the International Congress on Women in Organizations, Chicago, August 10.

De Villiers, D. 1986. Strategy for the development of small businesses and for deregulation. Pretoria, Ministry of Trade and Industry.

Devine, M. \& Clutterbuck, D. 1985. The rise of the entrepreneuse. EWMD Newsletter, Summer, 2, 6.

De Vries, M.F.R.K. 1977. The entrepreneurial personality: a person at the crossroads. J. Manage. Stud., 35-57.

Durand, D.E. 1975. Effects of achievement motivation and skill training on the entreprencurial behavior of black businessmen. Org. Behav. Human Perform., 14, 76-90.

Erwee, R. 1983. Widowhood and divorce as entrepreneurial opportunities. Entrepreneur, 2, 12, 9-11.

Erwee, R. 1986. Innovation despite adversity. Paper delivered at the Women's Bureau Congress, Johannesburg, September 5.

Erwee, R. 1987. Profiel van die Suid-Afrikaanse vroue-entrepreneur. Unpublished research report, University of Pretoria, January, 1-5.

Erwee, R. \& Pottas, C.D. 1982. Locus of control achievement motivation of managers. Psychologia Africana, 21, 79-102.

Gerdes, L.C. 1981. Die ontwikkelende volwassene. Durban, Butterworths.

Gilbert, A.J. 1980. The parameters of progress of black workers. Unpublished MA thesis, University of South Africa.

Gumpert, D.E. 1984. The other bottom line. Working Woman, July, 74-80.

Helm, S. 1986. Perfect Partners. Venture, July, 38-40.

Hisrich, R.D. \& Brush, C. 1984. J. Small Bus. Develop., January, 30-37.

Hoofstad Report. 1981. Swart vroue beter entrepreneurs as mans, Pretoria, Hoofstad, Augustus 1.

Human, P. 1984. Bureaucracy and the need for entrepreneurship in South Africa. S. Afr. J. Bus. Mgmt., 15, 212-219.

Krige, P. 1975. Family interaction patterns and achievement. Unpublished DPhil thesis, University of Port Elizabeth.

Kroon, J. 1984. 'n Struktuuranalise van Swartsakeondernemings in die Republiek van Suid-Afrika. S. Afr. J. Bus. Mgmt., 15, 182-187.

Kutumela, S.P. 1980. Existing training facilities for black businessmen. Paper at NIPR symposium, Pretoria, July.

Layman, A., Salganicoff, M. \& Hollander, B. 1985. Women in family business: an untapped resource. SAM Advanced Manage. J., Winter, 46-49.

Mkalipe, P. 1984. Black women in the labour market. $R S A$ 2000, 6, 8-11.

Moodley-Rajab, D. \& Ramkissoon, R.D. 1979. Internal-external locus of control among South African students - cross-cultural study. S. Afr. J. Psyhol., 9, 145-147.

Motsunyane, S. 1974. The problems facing black businessmen. IPB Journal, 12-13.

Munro, C. 1986. Home business; new work styles. Contact USA, 1, May/June, 5.

Naumes, W. 1978. The entrepreneurial manager in small business. Reading, Massachusetts: Addison-Wesley.

Nelson, G.K. 1979. Selection, identification and development of entrepreneurs and managers. Paper read at HSRC conference, Pretoria, September.

Noble, B.P. 1986. A sense of self. Venture, July, 34-36.

Ochshorn, S. 1986. I am my own boss, Venture, July, 46-49.

Perun, P.J. \& Bielby, D.D.V. 1981. Towards a model of female occupational behavior: a human development approach. Psychol. Women Quart., 2, 234-253.

Pollock, F.S. \& Pollock, J.C. 1986. The Venture Survey: Are you a risk taker? Venture, July, 24.

Pottas, C.D. 1981. Entrepreneurspotensiaal onder swart studente. Development studies of Southern Africa, 3, e, 243-261.

Pottas, C.D., Erwee, R., Boshoff, A.B. \& Lessing, B. (1980). Manual for the Achievement Motivation Questionnaire. Unit for Entrepreneurship, University of Pretoria, Pretoria. 
Riordan, Z.A.V. 1981. Locus of control in South Africa. J. Social Psychol., 115, 159-168.

Ruhe, J.A. 1986. Do women executives need different values, motives and skills to be successful in small rather than large businesses? Paper delivered at the Academy of Management Centennial, Chicago, August 12.

Rupert, A. 1985. Gesoek: die nuwe entrepreneur. Paper delivered at University of Pretoria, Pretoria, April.

Schreier, J.W. 1976. Is the female entrepreneur different? $M B A, 10$, March, 40-41.

Shapero, A. 1980. Some social dimensions of entrepreneurship. Working Paper Series, Ohio State University, August.

Shapero, A. 1985. Why Entrepreneurship? A Worldwide perspective. J. Small Bus. Manage., October, 1-5.

Slabbert, I. 1982. Navorsing rakende swart entrepreneurs. Human Sciences Research Council, Pretoria.

Sonnenfeld, J. \& Kotter, J.P. 1982. The maturation of career theory. Human Rel., 35, 19-46.
Surti, K. \& Sarupria, D. 1983. Psychological factors affecting women entrepreneurs: some findings. Indian J. Social Work, XLIV, 3, 287-295.

Timmons, J.A. 1979. Careful self-analysis can and team assessment can aid entrepreneurs. Harv. Bus. Rev., 57, 6, 198-206.

Van der Walt, S. 1984. 'n Kwantitatiewe beeld van die vrou in die werksituasie in die RSA. RSA 2000, 6, 27-35.

Van Rooyen, J. 1984. Developing the female labour force of South Africa - a challenge. RSA 2000, 6, 21-26.

Venture Magazine 1986. Series of articles on 'Women entrepreneurs: the new business owners'. Venture, July, 34-66.

Van Zyl, Y. 1985. Women in small business. Conference publication, Women's Bureau of South Africa, Pretoria.

Weinrauch, J.D. 1984. Educating the entrepreneur: understanding adult learning behavior. J. Small Bus. Manage., April, 32-37. 